\title{
Adolescent sexuality: practices and contraceptive problems in Douala (Cameroon)
}

\begin{abstract}
Introduction: According to the World Health Organization (WHO), adolescence is the period of growth between 10 and 19years of age. Complications from pregnancy are the second leading cause of death for adolescent girls aged 15 to 19 worldwide.

Objective: Our objective was to study the sexual practices of adolescent girls in secondary schools in the Douala $3^{\text {rd }}$ district as well as their contraceptive attitudes towards precocious pregnancies.

Methodology: We conducted a case-control analytical study from November $8^{\text {th }}, 2018$ to June $26^{\text {th }}, 2019$ in ten secondary schools in the Douala 3rd district. We matched, around the obstetric variable, a case group with this history to a control group who declared not to have had one and studied the different strategies used to avoid the occurrence of pregnancy. Data analysis was done using SPSS 20.0 software. The significance threshold was set at $\mathrm{p}<0.05$.

Results: A total of 445 consenting adolescent girls were selected, including 89 cases and 356 controls. The multivariate analysis of the results showed that the factors associated with the occurrence of teenage pregnancies were: an age greater than 17years $(\mathrm{aOR}=1.91$; $\mathrm{CI}=1.64-2.33$ ), being single with a boyfriend $(\mathrm{aOR}=6.48 ; \mathrm{CI}=3.33-12.60)$, the use of the male condom and the after pill $(\mathrm{aOR}=6.73 ; \mathrm{CI}=3.53-12.83$, $\mathrm{aOR}=4,34 ; \mathrm{CI}=1.86-10.11)$, find out about sexuality from your sexual partner or on social networks $(\mathrm{aOR}=2.24$; $\mathrm{IC}=1.11$ 4.54, $\mathrm{aOR}=1.78 ; \mathrm{IC}=1.01-3.13$ ), do not ask your parents ( $\mathrm{aOR} 2.20 ; \mathrm{IC}=1.31-3.70)$, alcohol consumption $(\mathrm{aOR}=2.01 ; \mathrm{IC}=1,23-3.29)$, multi sexual partnership $(\mathrm{aOR}=2.89$; $\mathrm{CI}=1.24$ 6.69), an age difference of more than 5years with partner ( $\mathrm{aOR}=2.24$; $\mathrm{CI}=1.16-4.35)$.
\end{abstract}

Conclusion: The teenager of the 3rd district of Douala is subject to early and unsafe sexuality and underuses family planning services which lead to precocious pregnancy.

Keywords: sexuality, adolescence, pregnancy, associated factors, Douala third
Volume II Issue 4 - 2020

Essome Henri, ${ }^{1,2}$ Eposse Ekoube Charlotte, ${ }^{1,2}$ Kedy Koum DC,' Egbe Obinchemti Thomas, ${ }^{3}$

Halle Ekane Gregory, ${ }^{3}$ Nana Njamen

Théophile, ${ }^{3}$ Boten Merlin, ${ }^{2}$ Tocki Toutou

Grace, ${ }^{2}$ Penda Ida Calixte, ${ }^{1,2}$ Foumane Pascal ${ }^{4}$

'Faculty of Medicine and Pharmaceutical Sciences of Douala, University of Douala, Cameroon

${ }^{2}$ Laquintinie Hospital of Douala, Cameroon

${ }^{3}$ Faculty of Health Sciences of Buea, University of Buea, Cameroon

${ }^{4}$ Faculty of Medicine and Biomedical Sciences of Yaounde, University of Yaounde I, Cameroon

Correspondence: Essome Henri, Faculty of Medicine and Pharmaceutical Sciences of Douala, University of Douala, Cameroon, Tel +237 696475672 , Email essometocky@yahoo.com

Received: July 15, 2020 | Published: August 12, 2020

\section{Introduction}

Adolescence is the period of growth and development that takes place between childhood and adulthood, that is to say 10 and 19years. It is a period of critical transition in life and is characterized by a significant rate of growth and transformation. It is a phase of preparation for adulthood during which key stages of development take place. ${ }^{1}$

Worldwide, around 16million adolescent girls aged 15 to 19 and one million adolescent girls under the age of 15 give birth each year; which represents nearly $11 \%$ of global births. $95 \%$ of these births take place in developing countries. ${ }^{2}$ Almost half of the countries in sub-Saharan Africa for which information is available are classified as "red", meaning that they have adolescent fertility rates above 100 births per 1,000 adolescent girls. These countries are those of West Africa, Central Africa, East Africa and Southern Africa. The proportions recorded by Niger, the Democratic Republic of Congo and Mali are among others high, with 192, 168 and 167 births per 1000 adolescent girls, respectively. ${ }^{3}$ Teenage pregnancies have been the subject of numerous studies around the world. According to a study conducted by Dryfoos in 1996 in the United States, early pregnancies are frequent in societies characterized by poverty, low education level and families headed by a mother who gave birth to their first child at adolescence. ${ }^{4}$ Teenage pregnancy is also associated with other problem behaviors, such as alcohol and drug use and early initiation of sexual activity, which have been identified as predictors of pregnancy. ${ }^{5}$ A study done in various European countries by Imamura et al. made it possible to group these factors into 5 groups: socio-demographic factors, family structure and stability, data related to education, behaviors risky for health, knowledge, accessibility and acceptability of family planning. ${ }^{6}$ According to the United Nations Population Fund (UNPF), in Cameroon, fertility remains early. The adolescent fertility rate represented $12 \%$ of general fertility in 2015 , while in 2018; this rate was $16.31 \%{ }^{7,8}$

Early pregnancies can have consequences on the health of adolescent girls (toxemia, anemia, nephropathy, cephalo-pelvic disproportion, hemorrhage, tears, obstetric fistulas, depressive disorders and maternal mortality) as well as that of the fetus they carry (low birth weight, fetal distress, and neonatal asphyxia, prematurity and fetal mortality). ${ }^{9}$ It is noted that the younger the mother, the greater the health risk for the child. This can be explained by the fact that these girls are more vulnerable than adult women to the risks of complications linked to pregnancy and birth, because not only their gynecological state is not ready and also their pelvic growth is not finished either. ${ }^{10}$ These pregnancy-related complications are the second leading cause of death for girls aged 15 to 19 worldwide. It is also noted that three million unsafe abortions take place among girls aged 15 to 19 each year, which increases maternal mortality and leads to lasting health problems. In Africa and Asia, around 13\% of maternal deaths are linked to unsafe abortions. ${ }^{9,11}$ Pregnancy in adolescent girls can also have economic and social consequences. Many young girls 
have to drop out of school when they become pregnant. However, a girl with little or no education will have fewer skills and less chances of finding a job. ${ }^{2}$

Considering the high prevalence of teenage pregnancies, the seriousness of complications and the maternal and fetal life prognosis at stake in the world, in Africa, particularly in Cameroon, we wondered about the sexual practice of adolescents of the 3rd district of Douala and the strategy it is developing to avoid the occurrence of pregnancy.

\section{Material and method}

\section{a. Type of study}

It was a case-control analytical study.

\section{b. Place of study}

We carried out our study in the city of Douala, specifically in secondary schools in the Douala $3^{\text {rd }}$ district. Ten schools were chosen randomly including 4 private secondary schools and 6 public secondary schools:

i. Oyack High School

ii. Bobongo Petit-Paris bilingual high school

iii. Ngodi-Bakoko Bilingual High School

iv. Nylon Brazzaville Bilingual High School

v. Nylon Technical School Douala

vi. Ndogpassi High School

vii. La Perfection Bilingual College

viii. 1Perle Bilingual College

ix. Piedjou Bilingual Multipurpose Institute

x. Pozam College.

The Douala $3^{\text {rd }}$ district is as cosmopolitan as the whole city and shines through a lack of urbanization. The commercial activity is the major one and it is usual to find businesses of all kinds surrounding the periphery of a school.

This is why we find near certain educational establishments in this administrative sub-division selling of alcoholic beverages, games rooms, hostels all reported in the literature as predictive factors for sexual depravity and early pregnancies. ${ }^{5}$

\section{c. Period and duration of the study}

We conducted our study from November $08^{\text {th }}, 2018$ to June $26^{\text {th }}$, 2019 , duration of seven months.

\section{d. Target population}

Our target population consisted of adolescent students from Douala $3^{\text {rd }}$ district.

\section{Source population}

Our source population consisted of all the secondary school students of Douala $3^{\text {rd }}$ district selected in our study.

\section{Inclusion criteria}

General inclusion criteria: Was included any student of one of the secondary schools of Douala 3rd having an age ranging between 10 and 19 years and agreeing to participate in the study with the informed consent of a parent.

Cases and controls: We matched, around the obstetric variable, a group of cases with this history to a control group which declared that they had not had any.

\section{Exclusion criteria}

Excluded from the study were those whose survey sheets were incomplete or poorly completed.

\section{Sample size}

The sampling method was continuous and exhaustive. The minimum sample size was calculated according to the Schlesselman formula below ${ }^{12}$ :

$$
n:\left(\frac{r+1}{r}\right) \frac{\bar{p}(1-\bar{p})\left(z \beta+\frac{z \alpha}{2}\right)^{2}}{\left(p_{1}-p_{2}\right)^{2}}
$$

$\mathrm{n}$ : Minimum size per group

r: Case-control ratio $(\mathrm{r}=1 / 4) 22$

p: Variability measure (similar to standard deviation)

$\frac{z \alpha}{2}:$ standardized level of significance $=1.96$

$\mathrm{Z}=$ Standardized power $=0.84$

$p_{l}$ : Prevalence of adolescent girls having started their reproductive life, i.e. $25 \%$ according to the 2011 EDS-MICS report in Cameroon. ${ }^{13}$

$p_{2}$ : prevalence of adolescent girls who have already had sexual intercourse, i.e. $81 \%$ according to the 2011 EDS-MICS report in Cameroon. ${ }^{13}$

After numerical application of this formula, the case group was made up of at least 83 cases for 332 controls with a total number of 415 participants.

The data were collected using a structured questionnaire and distributed after explanation to female students in their respective classes during recess in the absence of male students.'

The variables of interest for this study were socio-demographic (age, age of onset of pregnancy), data related to sexuality including risk behaviors, knowledge of family planning services and contraceptive methods.

\section{Data analysis}

Data was entered with CSPro 7.0 software and analysis was carried out using SPSS version 20.0 software. The variables were compared using the Chi-square and Fischer exact tests. The error threshold was set at $5 \%$ as statistically significant for each variable studied. The association between the variables was made using the odds ratio expressed with its $95 \%$ confidence interval. Logistic and linear regression was performed to eliminate the confounders.

\section{Results}

At the end of our recruitment, 445 girls were enrolled according 
to our inclusion criteria and divided into two groups according to the gestational variable; we therefore had a case group made up of those who declared having already been pregnant (89) matched with a control group (356) free of pregnancy (Figure 1).

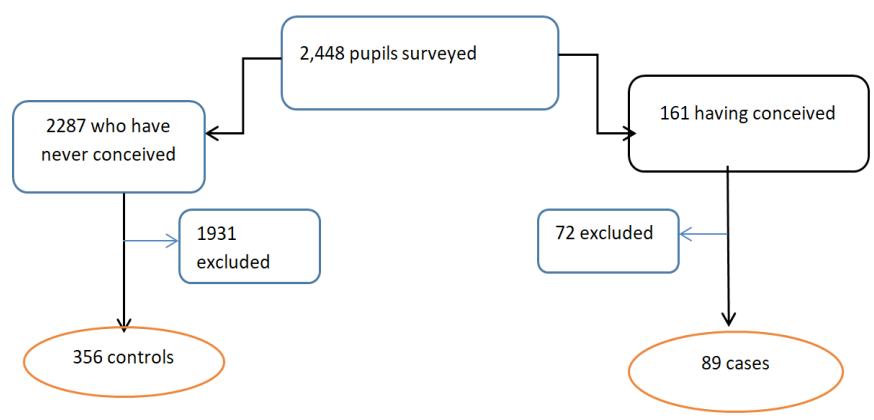

Figure I Distribution of the study population.

Regardless of the gestational history, 40.2\% (179 girls) of our study population were sexually active and $96.6 \%$ of these sexually active adolescent girls had their first coitus at 14years and above although their age at first coitus was not found as a factor associated with the onset of early pregnancy (Table 1).

Table I Distribution of the study population by age at first intercourse

\begin{tabular}{|c|c|c|c|c|c|}
\hline & & Cases & Controls & & \\
\hline Age at I & coitus & $\mathbf{N}=89$ & $\mathbf{N}=90$ & OR (Cl 95\%) & $\mathbf{P}$ \\
\hline$<14$ years & Yes & $3(3,4)$ & $4(4,4)$ & $0,76(0,17-3,29)$ & 0,711 \\
\hline$\geq 14$ years & Yes & $86(96,6)$ & $86(95,6)$ & I,0। $(0,95-I, 07)$ & \\
\hline
\end{tabular}

The male condom and the emergency pill were mainly used in the two groups with, however, significant exposure to pregnancy more than six times $(\mathrm{OR}=6.45)$ for the condom and seven times $(\mathrm{OR}=7.08)$ for the emergency pill.

Like other common contraceptive methods for these adolescent girls, we had periodic abstinence and interrupted coitus; but like the previous ones, the latter were also found as predictors of pregnancy because they significantly exposed them for periodic abstinence $(\mathrm{OR}=3.5)$ and interrupted coitus $(\mathrm{OR}=5.33)$ (Table 2).

Twenty percent of our sample (20\%) had already been pregnant and an age greater than $17 y$ years was found as a predictor $(\mathrm{OR}=1.44$; $\mathrm{CI}=1.31-1.59)$ of early pregnancy and this of significantly $(\mathrm{p}=0.000)$ (Table 3).

Finding out about sexuality from your sexual partner $(\mathrm{OR}=3.56)$ and on social networks $(\mathrm{OR}=1.64)$ has been found to be predictive factors for teenage pregnancy. However, asking parents about it was a protective factor $(\mathrm{OR}=0.62 ; \mathrm{CI}=0.44-0.88)$ (Table 4$)$. Only $30.3 \%$ of our adolescent population had knowledge of family planning services and only $4.6 \%$ claimed to have used it and all were in the case group. However we did not find a significant association with the occurrence of early pregnancy (Table 5).

We found a statistically significant association between unmarried adolescent girls with a boyfriend and the occurrence of adolescent pregnancies. Being single with a boyfriend multiplied the risk of early pregnancy by $1.68(\mathrm{OR}=1.68$; $\mathrm{CI}=1.48-1.90)$, while being single without a boyfriend was a protective factor (Table 6).
Table 2 Distribution according to the use of contraceptive methods

\begin{tabular}{|c|c|c|c|c|}
\hline & Cases & Controls & & \\
\hline Methods & $\begin{array}{l}N=89 \\
\text { n (\%) }\end{array}$ & $\begin{array}{l}N=356 \\
n(\%)\end{array}$ & OR (Cl 95\%) & $\mathbf{P}$ \\
\hline Periodic abstinence & $7(7,9)$ & $8(2,2)$ & $3,50(1,30-9,39)$ & 0,008 \\
\hline Interrupted coitus & $8(9,0)$ & $6(1,7)$ & $5,33(1,90-14,98)$ & 0,004 \\
\hline Menstrual cycle & $9(10,1)$ & $18(5,1)$ & $2,00(0,93-4,30)$ & 0,073 \\
\hline Male condom & $47(52,8)$ & $29(8,1)$ & $6,48(4,34-9,67)$ & 0,000 \\
\hline Spermicide & $0(0,0)$ & $0(0,0)$ & --- & ---- \\
\hline Pill & $I(I, I)$ & $0(0,0)$ & --- & 0,453 \\
\hline Injection & $0(0,0)$ & $0(0,0)$ & --- & ---- \\
\hline Implant & $0(0,0)$ & $0(0,0)$ & --- & ---- \\
\hline IUD & $0(0,0)$ & $0(0,0)$ & -- & ---- \\
\hline Diaphragm & $0(0,0)$ & $0(0,0)$ & --- & ---- \\
\hline Emergency Pill & $23(25,8)$ & $13(3,7)$ & $7,08(3,73-\mid 3,4 I)$ & 0,000 \\
\hline
\end{tabular}

Table 3 Distribution of the study population by age

\begin{tabular}{lllll}
\hline \multirow{4}{*}{ Age } & $\begin{array}{l}\text { Cases } \\
\mathbf{N = 8 9}\end{array}$ & $\begin{array}{l}\text { Controls } \\
\mathbf{N}=356\end{array}$ & OR (Cl 95\%) & p \\
& $\mathbf{n}(\%)$ & $\mathbf{n}(\%)$ & & \\
\hline$>$ I7years & $73(82,0)$ & $153(43,0)$ & $1,44(1,3 \mid-1,59)$ & 0,000 \\
$\leq 17 y e a r s$ & $16(18,0)$ & $203(57,0)$ & $0,32(0,20-0,50)$ & \\
\hline
\end{tabular}

Table 4 Distribution of adolescent girls according to the source of information on sexuality

\begin{tabular}{|c|c|c|c|c|c|}
\hline \multicolumn{2}{|c|}{$\begin{array}{l}\text { Source of } \\
\text { information on } \\
\text { sexuality }\end{array}$} & \multirow{2}{*}{ 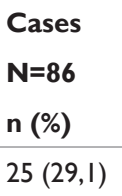 } & $\begin{array}{l}\text { Controls } \\
\mathrm{N}=340 \\
\text { n (\%) }\end{array}$ & OR (Cl 95\%) & $\mathbf{P}$ \\
\hline \multirow[t]{2}{*}{ Parents } & Yes & & $160(47,1)$ & $0,62(0,44-0,88)$ & 0,002 \\
\hline & No & $61(79,9)$ & $180(52,9)$ & $1,34(1,13-1,58)$ & \\
\hline \multirow{2}{*}{$\begin{array}{l}\text { Brothers/ } \\
\text { sisters }\end{array}$} & Yes & $15(17,4)$ & $77(22,6)$ & $0,77(0,47-1,27)$ & 0,294 \\
\hline & No & $71(82,6)$ & $263(77,4)$ & I,07 (0,95-I,19) & \\
\hline \multirow[t]{2}{*}{$\begin{array}{l}\text { Friends/ } \\
\text { comrades }\end{array}$} & Yes & $40(46,5)$ & $138(40,6)$ & I, I5 (0,88-I, I5) & 0,319 \\
\hline & No & $46(53,5)$ & $202(59,4)$ & $0,90(0,73-1,12)$ & \\
\hline \multirow[t]{2}{*}{$\begin{array}{l}\text { Sexual } \\
\text { partners }\end{array}$} & Yes & $27(3 \mid, 4)$ & $30(8,8)$ & $3,56(2,24-5,65)$ & 0,000 \\
\hline & No & $59(68,6)$ & $310(91,2)$ & $0,75(0,65-0,87)$ & \\
\hline \multirow[t]{2}{*}{$\begin{array}{l}\text { School/ } \\
\text { lectures }\end{array}$} & Yes & $29(33,7)$ & I $56(45,9)$ & $0,73(0,53-I, 0 I)$ & 0,052 \\
\hline & No & $57(66,3)$ & $184(54,1)$ & I,23 (I,02-I,47) & \\
\hline \multirow{2}{*}{$\begin{array}{l}\text { Television/ } \\
\text { radio }\end{array}$} & Yes & $23(26,7)$ & $100(29,4)$ & $0,91(0,62-1,34)$ & 0,625 \\
\hline & No & $63(73,3)$ & $240(70,6)$ & I,04 $(0,90-1,20)$ & \\
\hline \multirow[t]{2}{*}{ Social media } & Yes & $24(27,9)$ & $58(17, I)$ & $\mathrm{I}, 64(\mathrm{I}, 08-2,47)$ & 0,022 \\
\hline & No & $62(72, I)$ & $282(82,9)$ & $0,87(0,76-1,00)$ & \\
\hline \multirow[t]{2}{*}{$\begin{array}{l}\text { Socio- } \\
\text { educational } \\
\text { clubs at } \\
\text { school }\end{array}$} & Yes & $4(4,7)$ & $30(8,8)$ & $0,53(0,19-1.44)$ & 0,202 \\
\hline & No & $82(95,3)$ & $310(9 \mid, 2)$ & I,05 (0,99-I.II) & \\
\hline \multirow[t]{2}{*}{$\begin{array}{l}\text { Magazines/ } \\
\text { newspapers }\end{array}$} & Yes & $8(9,3)$ & $45(I 3,2)$ & $0,70(0,34-1.43)$ & 0,325 \\
\hline & No & $78(90,7)$ & $295(86,8)$ & I,04 (0,97-I.I3) & \\
\hline
\end{tabular}


Table 5 Distribution according to knowledge and consultation of family planning services

\begin{tabular}{llllll}
\hline \multicolumn{1}{l}{$\begin{array}{l}\text { Family planning } \\
\text { services }\end{array}$} & Cases & Controls & & \\
& & $\mathbf{n}(\%)$ & $\mathbf{N}=\mathbf{3 5 6}$ & OR (Cl 95\%) & p \\
\hline Knowledge & Yes & $31(34,8)$ & $104(29,2)$ & $1,19(0,79-1,65)$ & 0,302 \\
& No & $58(65,2)$ & $252(70,8)$ & $0,92(0,78-1,09)$ & \\
Consultation & Yes & $6(19,4)$ & $0(0,0)$ & ---- & 0,83 I \\
& No & $25(80,6)$ & $104(100,0)$ & & \\
\hline
\end{tabular}

Table 6 Distribution of the study population according to their relationship status

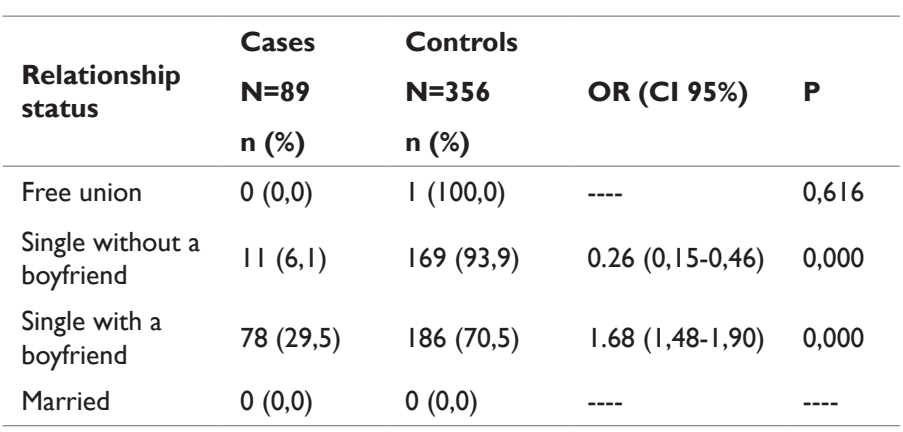

Alcohol consumption $(\mathrm{OR}=1.58 ; \mathrm{CI}=1.21-2.06)$, number of sexual partners equal to or greater than $2(\mathrm{OR}=2.26 ; \mathrm{CI}=1.16-4.40)$ and the difference in age greater than 5years between the adolescent and her partner $(\mathrm{OR}=1.39 ; \mathrm{CI}=1.03-1.86)$ were found significantly as factors associated with pregnancy in adolescent girls (Table 7).

In univariate analysis, it therefore appeared that the age above 17 years, being a teenager living with her boyfriend, as much as periodic sexual abstinence, the practice of interrupted coitus, the use of the male condom, emergency contraception, sexual information not from parents, in particular through social networks and the sexual partner, multi sexual partnership, alcohol consumption as well as an age gap of more than 5years with the partner were all found as predictors of early pregnancies because significantly exposing.

But in controlling confounders by logistic regression sexual abstinence and the practice of interrupted coitus were no longer (Table 8) (Table 9).

After multivariate analysis by logistic regression, the factors associated with the occurrence of teenage pregnancies were: being over 17years of age $(\mathrm{aOR}=1.91 ; \mathrm{CI}=1.64-2.33 ; \mathrm{p}=0.000)$, being single with a boyfriend $(\mathrm{aOR}=6.48 ; \mathrm{CI}=3.33-12.60 ; \mathrm{p}=0.000)$, use of male condom $(\mathrm{aOR}=6.73 ; \mathrm{CI}=3.53-12.83 ; \mathrm{p}=0.000)$, the use of the emergency pill $(\mathrm{aOR}=4.34 ; \mathrm{CI}=1.86-10.11 ; \mathrm{p}=0.001)$, finding out about sexuality from sexual partner $(\mathrm{aOR}=2,24 ; \mathrm{CI}=1.11$ 4.54; $\mathrm{p}=0.025$ ), finding out about sexuality on social networks $(\mathrm{aOR}=1.78 ; \mathrm{CI}=1.01-3.13 ; \mathrm{p}=0.045)$, not asking parents about sexuality $(\mathrm{aOR}=2.20 ; \mathrm{CI}=1.31-3.70 ; \mathrm{p}=0.003)$, alcohol consumption $(\mathrm{aOR}=2.01 ; \mathrm{CI}=1,23-3.29 ; \mathrm{p}=0.005)$, number of sexual partners equal to or greater than $2(\mathrm{aOR}=2.89 ; \mathrm{CI}=1.24-6.69 ; \mathrm{p}=0.014)$, age gap.

Table 7 Distribution according to the practice of risky behavior

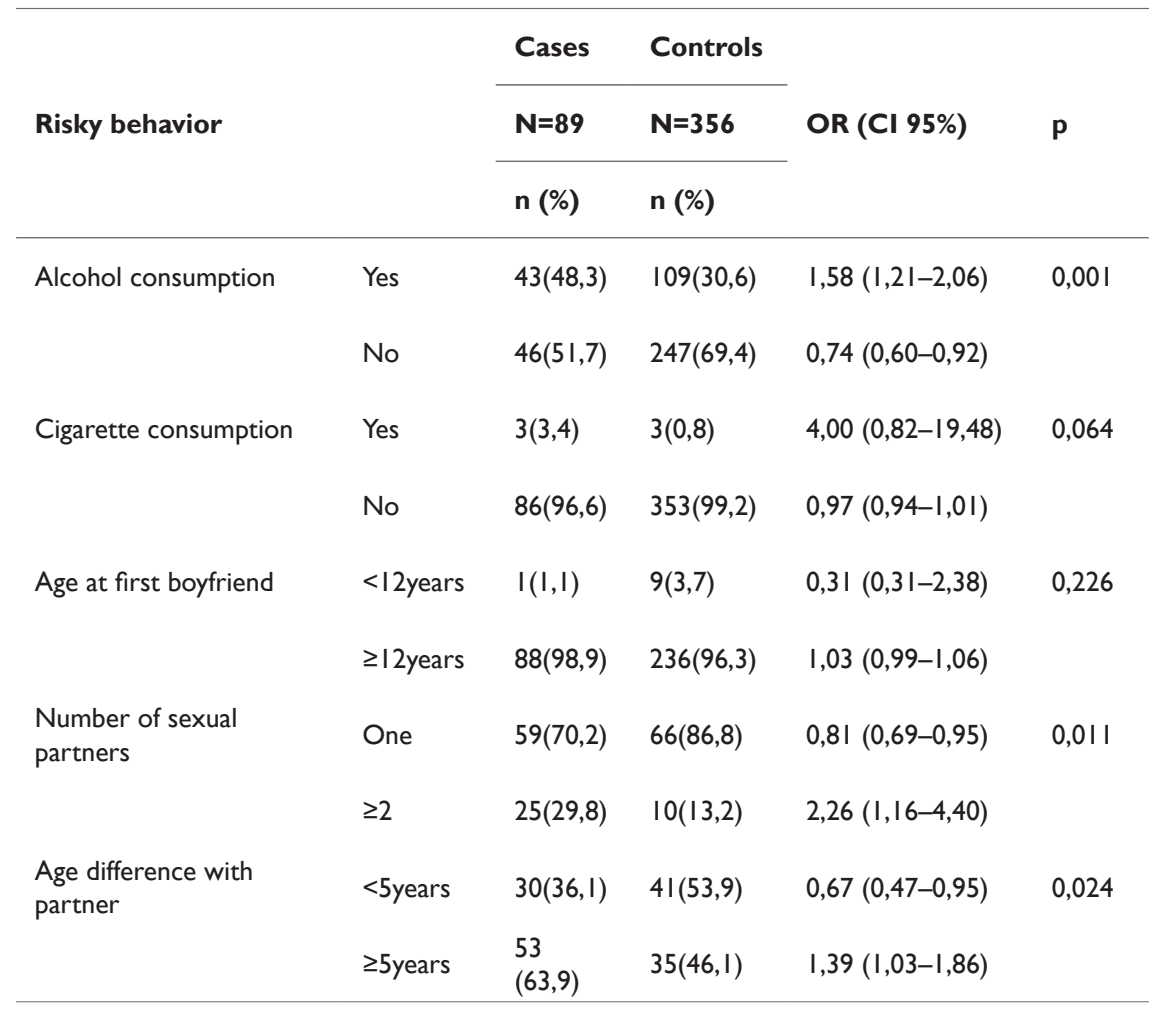


Table 8 Summary of risk factors for pregnancy

\begin{tabular}{|c|c|c|}
\hline Variables & OR (Cl 95\%) & $\mathbf{P}$ \\
\hline Age $>17$ years & $I, 44(I, 3 I-I, 59)$ & 0,000 \\
\hline Single with a boyfriend & $\mathrm{I}, 68(\mathrm{I}, 48-1,90)$ & 0,000 \\
\hline Use of periodic abstinence & $3,50(1,30-9,40)$ & 0,008 \\
\hline Use of interrupted coitus & $5,33(1,90-14,98)$ & 0,004 \\
\hline Use of male condom & $6,48(4,34-9,67)$ & 0,000 \\
\hline Use of emergency contraception & $7,08(3,73-|3,4|)$ & 0,000 \\
\hline Learning about sexuality from sexual partner & $3,56(2,24-5,65)$ & 0,002 \\
\hline Learning about sexuality on social networks & $\mathrm{I}, 64(\mathrm{I}, 08-2,47)$ & 0,022 \\
\hline Not learning about sexuality from parents & $1,34(I, I 3-1,58)$ & 0,000 \\
\hline Alcohol consumption & $\mathrm{I}, 58(\mathrm{I}, 2 \mathrm{I}-2,06)$ & 0,001 \\
\hline Number of sexual partners $\geq 2$ & $2,26(1,16-4,40)$ & 0,011 \\
\hline Age gap with sexual partner $\geq 5$ years & I,39 $(I, 03-1,86)$ & 0,024 \\
\hline
\end{tabular}

Table 9 Logistic regression of associated factors

\begin{tabular}{|c|c|c|}
\hline Variables & aOR (Cl à 95\%) & $\mathbf{p}$ \\
\hline Age $>17$ years & I,9I $(I, 64-2,23)$ & 0,000 \\
\hline Single with boyfriend & $6,48(3,33-12,60)$ & 0,000 \\
\hline Use of periodic abstinence & $2,06(0,54-7,88)$ & 0,290 \\
\hline Use of interrupted coitus & I,69 $(0,44-6,53)$ & 0,446 \\
\hline Use of male condom & $6,73(3,54-12,83)$ & 0,000 \\
\hline Use of emergency contraception & $4,34(I, 86-10, I I)$ & 0,001 \\
\hline Learning about sexuality from sexual partner & $2,24(I, I I-4,54)$ & 0,025 \\
\hline Learning about sexuality on social networks & $\mathrm{I}, 78(\mathrm{I}, 0 \mathrm{I}-3, \mathrm{I} 3)$ & 0,045 \\
\hline Not learning about sexuality from parents & $2,20(I, 3 \mid-3,70)$ & 0,003 \\
\hline Alcohol consumption & $2,01(1,23-3,29)$ & 0,005 \\
\hline Number of sexual partners $\geq 2$ & $2,89(1,24-6,69)$ & 0,014 \\
\hline Age gap with sexual partner $\geq 5$ years & $2,24(1,16-4,35)$ & 0,017 \\
\hline
\end{tabular}

\section{Discussion}

\section{Limits}

Adolescence is a period of delicate psychic growth; tackling such a delicate subject with an unaccomplished being was a handicap both in the approach and in the subjectivity of the responses collected; anything that can be a source of data understatement and cause statistical bias. The mask that emerges from our results is that of active sexuality from the age of 14 with registration in the obstetric register from the age of 17 and underuse of family planning services despite a significant knowledge of the contraceptive methods.
But what can we expect from the proper use of a condom by a 14-year-old girl whose source of information on sexuality is her boyfriend and social networks far from the family channel?

This mask translates all the distress of this growing being subjugated by a multitude of unsupervised solicitations and raises the problem of adolescence in a changing and unsafe African urbanity, just as it challenges the effectiveness of our family planning services. Better still, the comparison of our data with that of literature and the work of other authors is sometimes synergistic and sometimes dichotomous due to a socio-cultural difference. 
This means that the questioning is complex because it is societal and will probably not find a relevant explanation in the statistical test of findings without an elaborate overview of the sociological mirror including family impact and educational content.

\section{On the socio-demographic and gestational level,}

We registered 89 adolescent girls who declared that they had already been pregnant. Among them, $62.9 \%$ had had their pregnancy before 18 years; our results are close to those found by Gbaguidi in Benin in 2017 where $67.74 \%$ of adolescent girls were less than 18 years of age at the time of their pregnancy. ${ }^{14}$

Age greater than 17years $(\mathrm{aOR}=6.41 ; \mathrm{CI}=3.30-12.47 ; \mathrm{p}=0.000)$ was found as a factor significantly associated with pregnancy and joins the findings of Ayele et al. in northern Ethiopia where being $18-19$ years old was a risk factor for pregnancy. ${ }^{15}$

Being single with a boyfriend in our study population multiplied the risk of early pregnancy by $6.5(\mathrm{aOR}=6.48 ; \mathrm{CI}=3.33-12.60)$. Our results, paired with those of other authors, are dichotomous due to the work carried out in the context of early marriages; notably the case of Sakinatou in 2016 in Ngaoundéré ${ }^{16}$ and Ayele et al. ${ }^{15}$

\section{Data related to sexuality}

The use of the male condom $(\mathrm{aOR}=6.73 ; \mathrm{CI}=3.54-12.83)$, and emergency contraception $(\mathrm{aOR}=4.34 ; \mathrm{CI}=1.86-10.11)$ were found as predictors of early pregnancy like Mathewos and Mekuria in 2018 in southern Ethiopia who reported the use by young girls of emergency contraceptives with a lack of knowledge of the effective period of taking. This thus represented a risk factor for pregnancy $(\mathrm{aOR}=3.3$; $\mathrm{CI}=$ :1.4-7.4). ${ }^{17}$ According to Berrewaerts and Noirhomme, young people generally know about the existence of the main contraceptive methods but lack knowledge about their proper use. Their knowledge of the effective use or side effects of contraceptives is often inadequate, and based mainly on anecdotal information or on rumors. ${ }^{18}$ Despite knowledge of the existence of contraceptive methods, adolescent girls do not know how and when to use them effectively. A study carried out in Belgium in 2004 revealed that $52 \%$ of girls who had already experienced an unwanted pregnancy were using a contraceptive method: $34 \%$ the pill, $7 \%$ a condom and $11 \%$ another method. These figures show that the means of contraception and particularly the pill are not always used well. ${ }^{18}$ In addition, according to the WHO Pearl Index of the condom is 2 , while its practical effectiveness is $15 .{ }^{19}$

In our study population, the source of information about sexuality was a risk factor for early pregnancy; especially getting information about sexuality from sexual partner $(\mathrm{aOR}=2.24$; $\mathrm{CI}=1.11-4.54)$ and on social networks $(\mathrm{aOR}=1.78 ; \mathrm{CI}=1.01-3.13)$ and not asking parents about sexuality $(\mathrm{aOR}=2.20 ; \mathrm{CI}=1.31-3.70)$. Our results can be superimposed on those of Kanku and Marsh in 2010 in South Africa who argued that discussing important questions of sexuality with partner increases the risk of pregnancy in adolescent girls. They mention that the partner will tend to recommend not using a condom, as a sign of loyalty and love. ${ }^{20} \mathrm{Kanku}$ and Marsh also claim that the broad exposure of adolescent girls to social media increases the risk of teenage pregnancies..$^{20}$ According to Berrewaerts and Noirhomme, learning about sexuality from parents reduces the risk of pregnancy either by preventing or delaying teenage sex, or by advocating the use of contraceptives. Parents through their advice encourage healthy sexual behavior. ${ }^{18}$ Our results are different from those of Wado et al. in 2019 who claim that adolescent girls exposed to the media are less likely to be prone to early pregnancy. ${ }^{21}$ This difference could be explained by the fact that social networks can have a positive or negative influence on adolescent girls; it all depends on the sites and pages visited by them and their content.

\section{Risk behavior}

In our study, certain risk behaviors were found as predictors of early pregnancy; these include: alcohol consumption $(\mathrm{aOR}=2.01$; $\mathrm{CI}=1.23-3.29)$, multiple sexual partnerships $(\mathrm{aOR}=2.89$; $\mathrm{CI}=1.24-$ $6,69)$ and the age difference of 5 years or more between the sexual partner and the adolescent girl $(\mathrm{aOR}=2.24 ; \mathrm{CI}=1.16-4.35)$. Our results are similar to those of Imamura et al. in 2007, Kanku and Marsh in 2010, Faler et al. in 2013, Sakinatou in 2016, Jonas et al in 2016, and de Mathewos and Mekuria in 2018, who affirm that the consumption of psychoactive substances, particularly alcohol by adolescent girls puts them at risk of pregnancy. ${ }^{6,16,17,20,22,23}$ This is due to the fact that several teenage girls became pregnant as a result of unprotected sex which they allegedly had on the influence of alcohol. Jonas et al. in Brazil and Sakinatou in Ngaounderé, in their various studies have shown that adolescent girls who had several sexual partners were more at risk of early pregnancy $(\mathrm{OR}=1.25 ; \mathrm{CI}=1.04-1.50$ and $\mathrm{OR}=3.48 ; \mathrm{CI}=1.65-7.33) .{ }^{16.23}$ The difference in age greater than 5 years in our population increased the risk of pregnancy; our results are similar to those of Sakinatou in 2016 and Chung et al in 2018 that showed that the age difference greater than 5years with her partner was a predictor of teenage pregnancy. ${ }^{10,16}$ This is explained by the fact that adult partners more easily influence and manipulate adolescent girls in matters of contraception and sexuality.

\section{Conclusion}

The teenager of the 3rd district of Douala is subject to an early and unsafe sexuality which calls on all the actors of the education sector to undertake actions including sociological studies in order to better understand this phenomenon.

\section{Contribution of our study to science}

Despite the questions and limits mentioned above, our study brings to light the adolescent girl's torture after her menarche: harassment of all kinds and addiction make the bed of her daily life far from parental gaze. In order to ensure a harmonious development, it is appropriate to initiate a complementary study integrating the impact of the family tissue on adolescence in order to avoid conclusions of hemiplegic type i.e. partial.

\section{Contribution of authors}

a) Essome designed the study, collected the data and wrote the manuscript

b) Tocki carried out the literature review and edited the final version

c) Kedy Koum, Egbe, Eposse, Halle, Nana, Boten, Penda, have read and corrected the manuscript

d) Foumane directed the study and supervised the writing of the manuscript

e) All authors have validated the final version of the manuscript 


\section{Acknowledgments}

None.

\section{Funding}

None.

\section{Conflicts of interest}

The authors confirm the absence of any other conflict of interest that needs to be reported.

\section{References}

1. OMS. Développement des adolescents.Genève: Organisation Mondiale de la santé; 2018.

2. OMS. Grossesse chez les adolescentes. Genève: Organisation Mondiale de la Santé; 2018.

3. Hervish A, Clifton D. The status of adolescents and youth in sub-saharan Africa report: opportunities and challenge. Johannesburg: UNFPA; 2012.

4. Dryfoos JG. Adolescents at risk: prevalence and prevention. New York: Oxford University Press; 1991.

5. Coley RL, Chase-Lansdale PL. Adolescent pregnancy and parenthood. Recent evidence and future directions. Am Psychol. 1998;53(2):152-166.

6. Imamura M, Tucker J, Hannaford P, et al. Factors associated with teenage pregnancy in the European Union countries: a systematic review. Eur $J$ Public Health. 2007;17(6):630-636.

7. Cameroun. Fonds des Nations Unies pour la Population. Repositioning family planning as a development strategy. Yaoundé: UNFPA; 2015.

8. Kassa GM, Arowojolu AO, Odukogbe AA, et al. Prevalence and determinants of adolescent pregnancy in Africa: a systematic review and Meta-analysis. Reprod Health. 2018;15(1):195.

9. OMS. Pregnant Adolescents: Bringing a Promise of Hope to the World. Genève: Organisation Mondiale de la Santé; 2007.

10. Chung HW, Kim EM, Lee JE. Comprehensive understanding of risk and protective factors related to adolescent pregnancy in low- and middleincome countries: A systematic review. J Adolesc. 2018;69:180-188.

11. OMS. Early marriages, teenage pregnancies and young women. Genève: Organisation Mondiale Santé; 2012.
12. Vallin J, D'Souza S, Palloni A. Measurement and analysis of mortality: new approaches. INED; 1988. $486 \mathrm{p}$.

13. National Institute of Statistics, International Coaching Federation. Cameroon Demographic and Health Survey 2011. Maryland: Calverton; 2012:120-222.

14. Gbaguidi T. Grossesses en milieu scolaire dans l'arrondissement de Tchaourou (Bénin): niveau, profil des femmes concernées et conséquences en matière de scolarisation. Tchaourou, une commune béninoise. Éditions science et bien commun; 2017.

15. Ayele BG, Gebregzabher TG, Hailu TT, et al. Determinants of teenage pregnancy in Degua Tembien District, Tigray, Northern Ethiopia: A community-based case-control study. PLoS ONE. 2018;13(7):1-15.

16. Sakinatou D. Factors associated with the occurrence of teenage pregnancies in secondary schools in the city of Ngaoundéré. Yaoundé: Faculté de Médecine et des sciences biomédicales, Cameroun; 2016.

17. Mathewos S, Mekuria A. Teenage pregnancy and its associated factors among school adolescents of Arba Minch Town, Southern Ethiopia. Ethiop J Health Sci. 2018;28(3):287-298.

18. Berrewaerts J, Noirhomme-Renard F. Teenage pregnancies: what are the explanatory factors identified in the literature?. Bruxelles: uclouvain.be. 2006. $43 \mathrm{p}$.

19. Aubard Y, Azria E, Baldauf JJ, et al. Contraceptions. In: Dalila B, editor. National College of French Gynecologists and Obstetricians. 3rd ed. Paris: Elsevier Masson; 2015:19-23.

20. Kanku T, Mash R. Attitudes, perceptions and understanding amongst teenagers regarding teenage pregnancy, sexuality and contraception in Taung. South African Family Practice. 2010;52(6):563-572.

21. Wado YD, Sully EA, Mumah JN. Pregnancy and early motherhood among adolescents in five East African countries: a multi-level analysis of risk and protective factors. BMC Pregnancy Childbirth. 2019;19(1):59.

22. Faler CS, Câmara SG, Aerts DRG, et al. Family psychosocial characteristics, tobacco, alcohol, and other drug use, and teenage pregnancy. Cad Saúde Pública. 2013;29:1654-1663.

23. Jonas $\mathrm{K}$, Crutzen $\mathrm{R}$, van den Borne $\mathrm{B}$, et al. Teenage pregnancy rates and associations with other health risk behaviours: a three-wave crosssectional study among South African school-going adolescents. Reprod Health. 2016;13:50. 